\title{
Sonority Sequencing Violations and Prosodic Structure in Latin and Other Indo-European Languages
}

\author{
Jessica DeLisi \\ Program in Indo-European Studies University of California, \\ Los Angeles, CA, USA \\ jdelisi@ucla.edu
}

\begin{abstract}
Attention has been paid of late to syllable structure in ancient Indo-European languages, e.g. Sanskrit (Kobayashi, 2004), Latin (Marotta, 1999), Greek (Zukoff, 2012), Anatolian (Kavitskaya, 2001), and general Indo-European (Byrd, 2010; Keydana, 2012). There is little agreement in the field about some of the more difficult cases, most of which involve both word-initial and medial clusters that violate the Sonority Sequencing Principle (ssP), particularly sibilant-stop clusters. Because sibilants are more sonorous than stops, [STV- $]_{\sigma}$ onsets to roots such as ${ }^{*}$ ste $_{2}$ - require special consideration. I will argue that there are three types of evidence we can and should employ in attempting to diagnose syllable structure in ancient languages: metrical, phonological, and morphological. I will apply all three to Latin forms, showing that in Pre-Literary Latin, sibilantstop clusters formed true onsets, as Byrd (2010) has argued for Proto-Indo-European, but that by the Classical period these ssp-violating clusters were no longer licensed as onsets. In such sequences, Classical Latin allowed only $[t]$ in the onset, while the [s] formed a coda in medial position and was housed extraprosodically in word-initial position. The various treatments of ST-sequences in Latin and other Indo-European languages, especially PIE, Sanskrit, and Gothic, will be modeled in Optimality Theory using constraints on phonotactics and extraprosodicity.
\end{abstract}

\section{Keywords}

Latin - phonotactics - prosody - reduplication - phonology - Optimality Theory 


\subsection{Introduction}

Consonant clusters involving violations of the Sonority Sequencing Principle $[\mathrm{sSP}]^{1}$ are notoriously messy cross-linguistically (see, e.g., Cho \& King (2003), Vaux \& Wolfe (2009) for discussion and references). In Latin, there seems to be evidence both in support of a tautosyllabic branching onset [.ST] and of heterosyllabic [S.T] treatments. ${ }^{2}$ I will reexamine the evidence from Latin metrics, phonology, and morphology to determine the syllabification of sibilant-stop sequences and whether it can be demonstrated that this syllabification has changed over time.

This paper will be structured as follows. In $\S 1.2$, we will review the evidence concerning the prosodic structure of initial sibilant-stop clusters in Modern Romance languages. $§ 2$ will examine the most recent discussions of sT-clusters in Latin. In $\S 3$, I will review the three different types of evidence we have for syllable structure in historical languages: metrics ( $\$ 3.1)$, synchronic phonology (§3.2), and morphology (§3.3). It will be shown that all three support the conclusion that ST-clusters were not tautosyllabic by the Classical Latin period; however, phonological and morphological evidence will show that ST-clusters had been tautosyllabic prior to the historical period. $§ 4$ will present the conclusions.

\subsection{Sibilant-Stop Clusters in Modern Romance}

Evidence from Modern Romance languages suggests that the Ss P is now highly ranked. ${ }^{3}$ For example, Spanish and Portuguese allow complex onsets only if there are no SSP violations. Violations of the SSP in initial position are repaired through epenthesis, a process which must be synchronically active since it occurs in both loan adaptation and L2 phonological errors as well. This epenthetic vowel is also invisible to stress assignment (Harris, 1970: 929), and thus it must be outside the stress domain. Evidence of this epenthesis phenomenon can also be found in Vulgar Latin inscriptions as early as the 2nd c. AD (Weiss, 2009: 511):

1 A phonotactic principle dictating that well-formed syllables should consist of a sonority peak at the syllable nucleus, with onset and coda segments reducing in sonority toward the margin. That is to say, [trert] is wellformed according to the ssp, but [rtetr] is not. In Latin, as most languages, the sonority scale is: glides $\gg$ liquids $\gg$ nasals $\gg$ fricatives $\gg$ stops.

2 Here and following, $\mathrm{C}=$ consonant, $\mathrm{T}=$ stop, $\mathrm{V}=$ vowel, $\mathrm{R}=$ sonorant, $\mathrm{H}=$ laryngeal, $\mathrm{s}=$ sibilant. [.] indicates a syllable boundary. $<>$ indicates an extraprosodic segment.

3 Romanian presents an exception to this generalization (Marin, 2013). 
(1) Prothesis in Vulgar Latin inscriptions:

(a) ISTERCORIVS = Stercōrius (personal name, CIL 6.12171),

(b) ISPOSE = spōnsae 'spouse' (CIL 8.3485)

Furthermore, in some dialects of Portuguese, ${ }^{4} / \mathrm{s} /$ becomes [ $\left.\int\right]$ when in a coda or in a medial /sT/ cluster. The most parsimonious explanation, of course, is that medial /sT/is heterosyllabic. Therefore, we can conclude that SsP violations are banned in all Portuguese onsets, both in word-initial and word-medial position.

While Italian shows surface sT-clusters in initial position, they function quite differently in the synchronic grammar than CR clusters. ST-initial words take the $l o$ allomorph of the definite article rather than the expected $i l$ seen with other C-initial words (Hermes et al., 2013: 2):

(2) Definite article allomorphy in Italian:

(a) il cliente 'the client'

(b) lo sport 'the sport'

Further, raddoppiamento sintattico fails to apply across word boundaries if the second word is ST-initial (Hermes et al., 2013:3):

(3) Italian raddoppiamento sintattico:

(a) a presto $\rightarrow$ ['ap'presto] 'see you soon'

(b) città sporca $\rightarrow\left[\mathrm{t} f \mathrm{fit}^{\prime}\right.$ tas $\left.\underline{\text { porka }}\right]$ not *[ $\mathrm{t} \mathrm{f}$ it'tass'porka] 'filthy city'

Studies of articulatory phonology on Italian speakers show that ST and TR clusters have systematically different structures. TR clusters time like branching onsets, while sT clusters do not:

Whereas in $/ \mathrm{pr} /$, both $/ \mathrm{p} /$ and $/ \mathrm{r} /$ have distinct coordination patterns as compared to either $/ \mathrm{p} /$ or $/ \mathrm{r} /$ as a single consonant in the same (wordinitial) position, this is not the case for $/ \mathrm{sp} /$. Here the $/ \mathrm{p} /$ patterns like a single consonant: $/ \mathrm{p} /$ in spina patterns with $/ \mathrm{p} /$ in Pina (proper name). Thus, although /s/ in spina constitutes a word onset, there is evidence against it being part of a syllable onset.

HERMES ET AL., 2013:1

4 Including varieties from Portugal, the Brazilian variety from Rio, and African varieties. 
(a) $\mathrm{CC}$ clusters

gestural
coordination (b) SC clusters

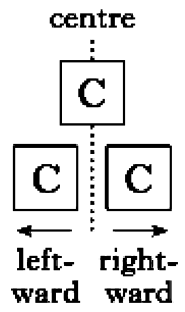

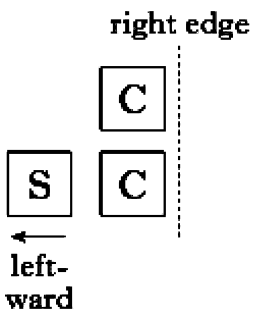

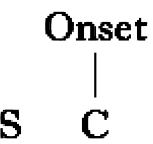

syllable
onset

FIGURE $1 \quad c$-Centering of Italian branching onset clusters $(a)$ vs. sc clusters $(b)$ HERMES ET AL., 2013: 7

The timing studies show that, in true branching onsets like those of the type CR in Italian, the two consonants effectively push each other around the center of the onset timing slot, so that the first consonant is slightly earlier than would be expected for a simplex onset and the second encroaches somewhat on the vowel slot. Italian sT clusters, on the other hand, do not show this Ccentering effect; instead, it is only the second consonant that is coordinated with the vowel, as if the first consonant were not present. Thus, though the ST forms a word-initial cluster, it is not accurate to say that it is a true branching onset. Throughout, I will distinguish between clusters, meaning two adjacent consonants not necessarily dependent upon the same prosodic structure, and branching onsets, where the two consonants form a prosodic unit dependent upon a single onset node.

The timing data drawn from the articulatory phonological experiments support the conclusion that Italian ST-clusters are not tautosyllabic. In medial position, the $\mathrm{s}$ forms the coda to the previous syllable; in initial position, the $\mathrm{s}$ is extraprosodic, creating a structure like that in Figure 1 above. The $s$ is pushed leftward precisely because the $\mathrm{s}$ is extraprosodic, and therefore not licensed within the same prosodic word as the T-.

The most recent examination of the historical phonology of Latin ST-clusters was by Keydana (2012), who compares the reduplication of Latin spopondī 'pledged' with Gothic staistald 'possessed.' In both Latin and Gothic, the redu- 
plicant of /st/-initial roots is [sT-], leading Keydana to conclude that "[i]f the reduplicant offers only one slot for a non-peak segment, /sT/ in onsets must count as one segment in Latin and Gothic" (Keydana, 2012: 102). In other words, rather than forming a true cluster, the $\mathrm{s}$ in this position is subsegmental, creating something akin to a backwards affricate.

The major benefit to Keydana's analysis is that, because the domain of the ssP is the syllable and monosegmental clusters are smaller than syllables, the sSP is not reduced to a mere tendency (Keydana, 2012: 103). However, Keydana has formulated his analysis in Optimality Theory (от), a major tenet of which is that all constraints are potentially violable, therefore violations of the SSP are predicted to be possible when other constraints on wellformedness are ranked higher in the grammar. As I will show in $\S 3.3$ below, treating the sSP as a violable constraint ranked against other violable constraints generates the great variety of reduplication grammars in the Indo-European family.

There is a further trouble with Keydana's approach: it directly contradicts the phonetic evidence. Crosslinguistically, ST clusters consistently time as two separate segments. Although languages may differ on the precise timing details depending on whether or not the cluster syllabifies as a tautosyllabic branching onset (see the discussion of Italian in $\S 1.2$ above), to my knowledge there are no languages that treat ST as a monosegment in the sense Keydana intends here. Note also that Keydana's analysis requires Latin and Germanic to develop these monosegmental ST clusters independently, since they were not present in the PIE period. In Italic, these are relatively short-lived - they are gone by the Old French period (Keydana, 2010: 4, fn. 9) - but in Germanic they must persist through to the present day (but see $\S$ 3.4.2 on Gothic below).

\section{3}

\section{Evidence for Syllable Structure}

In studying modern languages, phonetic experiments can offer strong evidence for syllabification; however, the lack of native speakers prevents us from accessing such direct evidence for ancient languages. Instead, there are three types of evidence we could examine to determine the syllabification of such a language: metrical (assuming the language in question has quantity-sensitive syllable counting meter), phonological (assuming the language has phonological or prosodic processes sensitive to syllable weight or syllable position), and morphological (again, assuming the language has morphological processes sensitive to syllable weight or position). Not all types of evidence may be available in all languages: e.g., Classical Armenian has no metrical evidence to shed light on its syllabification. 


\subsection{Metrical Evidence}

The earliest large body of metrical evidence we have for syllable structure comes from the Early Republic authors, especially Plautus, Terence, and Ennius. The metrical evidence for this period is conflicting: syllables with short vowels before medial sibilant-stop clusters sometimes scan long by position and sometimes short. The first scansion implies heterosyllabic ST-clusters (-vs.TV-), while the latter implies tautosyllabic clusters (-V.STV-). In reexamining the corpus, ${ }^{5}$ Fortson (p.c.) was only able to find three examples of short scansion for words of the shape-statem, and in all three examples the cluster is in the same metrical position and the same meter: ${ }^{6}$

(4) Short scansion before medial sT-clusters in Plautus:

(a) pater, et poteris et ego potero, et di eam potestatem dabunt (Cap. 934, trochaic septenarius)

(b) quia sine omni malitiast, tolerare eius egestatem uolo. (Trin. 338, trochaic septenarius)

(c) nolo ego mihi te tam prospicere qui meam egestatem leues (Trin. 688, trochaic septenarius)

In all examples of so-called Brevis Brevians (where a syllable unexpectedly scans short rather than long after another short syllable), the syllable in question is directly pretonic. This observation has led scholars to assume that accent must have something to do with Brevis Brevians, although the exact details of the explanation differ from treatment to treatment. ${ }^{7}$

Medial sT-clusters are not alone in behaving this way in the texts of Plautus, though. Words with other clusters also scan with light syllables before the main stress:

(5) Short scansion before other clusters (Fortson, 2008: 210-213):

(a) ducentos et mille Philippum. :: Tantum debuit. (Bac. 272, iambic trimeter)

5 In his 2008 book, Fortson claimed that short vowels before sT clusters systematically scanned short in direct pretonic position (i.e., [- $\breve{v}(\mathrm{c}) \breve{v}$ sTv́-]); however, upon reexamining the corpus, the data does not actually support his claim. So-called "Brevis Brevians," "iambic shortening," or "correptio iambica" with sT-clusters turns out to be quite rare in the corpus of Plautine poetry.

6 All Plautus examples are from Lindsay (1904-1905).

7 See, for example, Fortson (2008: 206) and Halporn et al. (1980: 65). 
(b) dum tibi nunc haec aetatulast, in senecta male querere (Mos. 217, iambic septenarius)

(c) si tuas esse oportet niue eas oportet esse liberas (Rud. 714, trochaic septenarius)

Unless we are willing to accept [nt-], [ct-], and [rt-] onsets in Latin, it does not seem to me that syllabification can truly explain the scansion of these words. Perhaps SSP-violating onsets were no longer synchronically licensed in Plautus's time, and thus the variants with [V.sTv́] are nothing more than poetic conventions; in fact, I will argue below that the synchronic phonology demands a non-tautosyllabic treatment of ssP-violating clusters by the beginning of the literary period (see $\$ 3.2$ below). Plautus may have been aware of earlier or regional pronunciations with /sT/ branching onsets, and used this syllable structure where metrically convenient. Brevis brevians of this kind then seems to be merely a feature of Latin poetry, and not a synchronic prosodic process in the regular phonology.

By far more common is long scansion, implying heterosyllabic treatment of the cluster (-vs.TV-). Examples from Plautus abound:

(6) Long scansion of medial sT-clusters in Plautus:

(a) Amor, Voluptas, Venus, Venustas, Gaudium (Bac.115, iambic senarius)

(b) Plus dabo quam praedicabo ex me uenustatis tibi. (Mil. 651, trochaic septenarius)

(c) amoenitates omnium uenerum et uenustatum adfero (St. 278, iambic octonarius)

By the Classical Latin period, long scansions before medial st become the norm:

(7) Long scansions before medial st in Classical Latin: ${ }^{8}$

(a) exciderant animo manet ala mente repostum (Vergil Aeneid I.26)

(b) (quid non sentit amor?) primi vidistis amantes (Ovid Met. IV.68)

(c) eheu fugaces, Postume, Postume (Horace, Odes II.3.27)

Whatever the explanation for Brevis Brevians in the Early Republic poets may be, the phenomenon is no longer active before sT-clusters in the Classical

8 For the Classical texts, I used Wickham (1922), Mynors (1978), and Tarrant (2004). 
period; instead, the meter by the classical period has come in line with what will be shown in the phonology and morphology of the period: medial st clusters are heterosyllabic.

\subsection{Phonological Evidence}

Any phonological processes that are sensitive to syllable weight should reveal whether -sT- closes a syllable or not. In Latin, there are three sources of evidence: short vowel syncope, vowel weakening, and stress placement. Below, I will assume the following relative chronology:

(8) Relative Chronology of Latin sound changes:

1 Prehistorical changes: Initial stress and short vowel syncope

2 Pre-Literary changes: Medial vowel weakening and Classical stress placement

The Prehistorical changes predate inscriptional material, while the Pre-Literary changes postdate some inscriptional material, but predate the attestation of Early Republic poets. The two changes within each period do not appear to directly interact with each other for the purposes of sT-cluster assignment, and therefore the relative dating of initial stress versus vowel syncope and vowel weakening versus Classical stress placement will not be discussed below.

3.2.1 Syncope and Weakening of Non-Initial Vowels

A small number of forms showing syncope of short vowels before medial -STclusters are cited by Nishimura (2011: 17-20):

(9) Open Syllable Syncope:

(a) miscellus < *mi.nu.scel.lus 'hybrid'

(b) fèstra [P.F. 80.27L] / fênstra [some mss of Plautus] < ${ }^{*}$ fe.ne.stra 'window'

(c) mōnstrum $<{ }^{*}$ mo.ne.strum 'portent'

Because short vowel syncope otherwise occurred only in open syllables, the ST-cluster must have still syllabified as a tautosyllabic onset at this time. In all forms showing syncope before -ST-, the affected vowel is in a sequence of two open syllables, an environment Nishimura demonstrates to have been targeted by syncope early in the Pre-Literary period (Nishimura, 2011: 16).

The other relevant phonological process sensitive to syllable structure was vowel weakening, a process of reduction in non-initial syllables. As is well known, there is a general tendency in Latin for vowels to reduce to [i] in open 
syllables and [e] in closed syllables (Weiss, 2009:116 ff.). Examples of weakening before -ST-include (Marotta, 1999: 300-301):

(10) Closed Syllable Weakening:

(a) infestus 'disturbed' if related to fastus 'contempt, haughtiness'

(b) incestus 'impure' cf. castus 'pure' (ibid.)

Both examples clearly point toward a closed syllable development, contrasting with the syncope process above. The only form to contradict this generalization is praefiscinī, an apotropaic adverb related to fascinum 'evil spell, phallic emblem' (Weiss, 2009: 123, fn 37), but this word is considered anomalous enough to receive special treatment by Nishimura (2011: 19, fn 34), Juret (1919: 95), Rix (1966: 157 , fn 3), and Adams (2007: 281, and fn 16). Perhaps, as Rix (1966: 157 n. 3) and Sommer \& Pfister (1977: 55) claim, the [i] is due to vowel assimilation. ${ }^{9}$

The most parsimonious way to explain the different treatment of vowels before sT-clusters by the two phonological processes is to ascribe them to different chronological strata of the language. As mentioned above, syncope in a sequence of short syllables occurred in the Pre-Literary period. Closed syllable weakening of the *incastus > incestus type also occurred very early, but it appears to have been a historical event; evidence of non-weakened forms can be found in the famous Duenos inscription, the Praenestine Fibula, and some inscriptions from fifth century Satricum (Nishimura, 2008: 11-12):

(11) Inscriptions predating Closed Syllable Weakening:

(a) IOVESAT 'iurat, swears,' not ** IOVISAT (DUENOS inscription)

(b) FECED 'made,' not ** FECID (DUENOS inscription)

(c) FHE:FHAKED 'fecit, made,' not **FHE:FHIKID or **FHE:FHIKID (Praenestine Fibula)

(d) MAMARCOM (575-525 B.C.E.) and MAMARTEI (CIL r2 2832a Satricum, ca. 500 B.C.E.), not Classical Mamertīn̄ (personal name)

The inscriptional evidence points to a later date for weakening than for the syncope of vowels in a sequence of open syllables. Weakening must have been relatively late in the Pre-Literary period but certainly before the onset of the Literary period, when forms with weakening are found in abundance.

9 Additionally, one reviewer suggested that the anomalous vowel outcome may be due to this word's usage as an interjection. 
This relative chronology supports a historical change from tautosyllabic to heterosyllabic treatment as the Sonority Sequencing Principle was promoted in the constraint rankings, making ST-clusters illicit as true branching onsets.

\subsubsection{Stress Placement}

Another well known phonological feature of Latin is the classical penult stress rule: if a word is three syllables or longer, the penult was stressed if it was heavy. If the penult was light, the antepenult was stressed. As was already pointed out by Marotta (1999:300-301), words with medial sT-clusters after the penult vowel such as dēsísto 'leave off', inféstus 'hostile', incéstus 'unchaste' have penult stress, rather than antepenult stress. Therefore, these words furnish further evidence that by the time the penult stress rule was applied, the sT-cluster must have been heterosyllabic; had it been tautosyllabic, the penult would have been light and these words would have been assigned antepenult stress.

On the other hand, many of the forms cited in $\S 3.2 .1$ to demonstrate opensyllable syncope, such as ${ }^{*} f e . n e . s t r a \rightarrow f \bar{e}(n)$ stra, require initial stress, since the medial [e] wouldn't have deleted if under stress (i.e., the penult rule would require fe.nés.tra like dēsistō). This is further consistent with Nishimura's dating, as the initial stress period was a feature of Pre-Literary Latin, whereas the penult stress pattern we see in désístō was Classical.

\subsection{Morphological Evidence: Reduplication}

The form sistō 'set up (1sg. pres.)' is usually invoked to demonstrate that Latin allowed SsP-violating onset clusters. However, this form is a relic divorced from the rest of the grammar of the language, since no other verb reduplicates in this way and it's easily compared with Avestan, and, with a slightly different stem formation, Greek. There is a slightly more robust pattern: the spoponditype. Not only is this type of reduplication associated with more stems (three: spopondī 'pledged (1sg. perf)', stetī 'set up (1sg. perf)', scicidī 'split (1sg. perf)' as opposed to one), it is also anomalous both cross-linguistically and within the Indo-European world.

In his study on Latin reduplication, André $(1978: 10, \mathrm{fn} 4)$ dismisses the type as a trivial dissimilation from ${ }^{*}$ ste-st ${ }^{2}{ }^{2}$, although he does not address the fact that reduplication of initial clusters is extraordinary in the synchronic grammar. Fleischhacker (2005: 24-26) claims that the spopondi-type of reduplication is infixation (i.e., [spo-RED-ndi] with [po] infixed in the root [spond]), but, as Keydana (2010:5, fn19) has already pointed out, Latin is not generally an infixing language. There is only one inherited verbal infix, the nasal present marker, and it is not particularly clear that it was synchronically analyzable as such, any more than the $-n$ - in English stand-stood is. The frequent spread of the 
nasal marker from present stems to perfect stems casts further doubts on its synchronic analyzability - this is not the behavior one would expect from a synchronic present marker.

Below I will propose that the variant behavior of reduplication in Gothic and Latin as described by Keydana (2012), as well as that of PIE and Sanskrit, can be motivated purely through phonotactics and constraints on the size and position of root and reduplicant morphemes. This analysis will not require the addition of new kinds of segments to the Latin inventory, like Keydana's monosegments; instead, I will propose that both PIE and Gothic phonotactics allowed branching onsets with falling sonority, but Latin and Sanskrit independently lost these onsets, causing a disruption in the way sT-initial roots were reduplicated. The phonotactic problems presented by ST-initial roots were solved in different ways by Sanskrit and Latin, mirroring their different rankings of these constraints in their respective grammars.

\subsubsection{Optimality Theory}

Optimality Theory (Prince \& Smolensky, 1993/2004) is a method of modeling grammar as a series of competing violable constraints on possible output forms. For any input form ${ }^{10}$ an infinite candidate set of possible outputs is generated. These candidates are evaluated against two types of constraints: markedness constraints penalize the realization of marked structures in the output, and faithfulness constraints penalize deviation from the original input form. Depending on the ranking of these constraints, the candidate that best satisfies the highest ranked constraints will be selected as optimal, i.e. the surface form generated by the grammar.

The interaction among inputs, constraints, and outputs is depicted in tableaux:

TABLE 1 Illustration of a typical ot tableau

\begin{tabular}{|r||c:c|c|}
\hline /input/ & CONSTRAint 1 & CONSTRAint 2 & CONSTRAint 3 \\
\hline \hline a. candidate a & $* !$ & $*$ & $*$ \\
\hline b. candidate b & & $* !$ & \\
\hline$\rightarrow$ c. candidate c & & & $*$ \\
\hline
\end{tabular}

10 от inputs are similar to underlying forms in rule-based phonology. 
In this illustrative mini-tableau, three potential candidates (a, b, and c) are evaluated against three constraints $(1,2$, and 3$)$. Violations are marked with an asterisk. A fatal violation, i.e. the violation that eliminates a candidate from consideration, is marked with both an asterisk and an exclamation mark. Elimination is also signaled by cell shading. Candidate a violates all three constraints. Candidate b violates only constraint 2. Candidate $\mathrm{c}$ is chosen as the optimal output candidate, indicated with the pointer finger icon, because it satisfies both of the highly ranked constraints $(1$ and 2$)$. While candidate $c$ does violate constraint 3 , this violation is non-fatal because all of the other candidates have already been eliminated.

Ideally, a critical ranking should be demonstrated for all constraints (i.e., that in one ranking, the correct optimal candidate is selected, whereas in the opposite ranking an incorrect optimal candidate would be selected). Just such a ranking can be demonstrated for constraints 2 and 3; constraint 2 must be ranked higher than constraint 3 because the winning candidate violates constraint 3 but not constraint 2 . In this tableau, constraints 1 and 2 cannot be critically ranked since either ranking ( $1 \gg 2$ or $2 \gg 1)$ would select the correct output candidate. Critical rankings are indicated with a solid line between the two columns. The dotted line between constraint 1 and constraint 2 indicates that no critical ranking could be found based on just these candidates.

от can model diachrony through changes in constraint rankings from one stage of grammar to the next." ${ }^{11}$ As children learn the grammar of the language (i.e. the constraint rankings), constraints that do not directly interact will create dilemmas for learners. If children assume a different ranking for these constraints than the adults use, a change in the grammar will result. The majority of rerankings likely stem from innocent misapprehension of constraint rankings as learners acquire the grammar.

Some surface structures may be compatible with multiple rankings. Wordinitial sT-clusters present just such a case; speakers do not seem to be sensitive to the subtle phonetic distinction between extraprosodic $[<\mathrm{S}>\mathrm{T}]$ and tautosyllabic [sT-] pronunciations revealed by Articulatory Phonology experiments. Thus, learners encountering sT-initial words are forced to make a decision when presented with /sT-/ words: is it better to created a structure that violates the ssP and allow a branching onset with falling sonority, or is better to violate normal alignment constraints and allow clusters across a prosodic boundary

11 For a more complete discussion of от in diachrony, see Green (1997), Cho (1998), Holt (2003), Kiparsky (2004). For an argument that от is not suited to diachronic studies at all, see McMahon (2000). 
(i.e. allow an extraprosodic segment). Below, I will demonstrate that PIE and Pre-Latin speakers acquired the first grammar, but that by the Classical Latin period, speakers had changed to the latter grammar. Since sT-clusters are the only SSP-violating clusters in Latin, unambiguous data would have been lacking, allowing for the observed change in ranking to occur eventually.

\subsubsection{Constraints}

The difference in reduplication among the four Indo-European languages below can be modeled through variable ranking of five constraints on prosodic structure and alignment:

1 SSP (Sonority Sequencing Principle, Onsets): Branching onsets should increase in sonority toward the nucleus.

$2{ }^{*} \mathrm{M} / \mathrm{A} \triangleright \mathrm{T}$ (Margin Hierarchy, Onsets): Simplex onsets are more preferred the lower the sonority of the margin segment. One violation per non-stop margin segment.

In principle, this constraint would apply to both root and reduplicant onsets; however, in practice, faithfulness constraints (not shown below for presentational ease) will prevent this constraint from forcing all simplex onset segments in Latin to turn into stops. That this constraint will be effective in reduplicant onsets is an example of a TETU (The Emergence of The Unmarked) effect (see Becker \& Potts, 2011).

3 RED-L:The left edge of the reduplicant should correspond with the left edge of the prosodic word. Assign one violation per misaligned segment.

Since extraprosodic segments are by definition outside the prosodic word, they would cause a violation of this constraint. ${ }^{12}$

4 Rоот-L: The left edge of the root should correspond with the left edge of the prosodic word. Assign one violation per misaligned segment.

This constraint will be violated by any segments to the left of the root (in this case, the reduplicant). By penalizing reduplicant segments, the grammar encourages the shortest possible realization of the morpheme.

12 For more on the structure of extraprosodicity, see DeLisi (2015: 88-103). 
5 Rоoт, $\Sigma$-L: The left edge of the root should correspond with the left edge of the syllable. Assign one violation per misaligned segment.

Based purely on the evidence of reduplication, I will only be able to achieve partial rankings for these five constraints in each of the four grammars below. To further simplify the tableaux, I will omit conceivable candidates that are harmonically bounded (i.e., there is no ranking according to which it could win). For example, the possible PIE candidate * stis.teh.$t i$, with a branching onset in the reduplicant but heterosyllabic [s.t] in the root will not be included below; in a grammar preferring branching ST onsets, this candidate would be beaten by candidate ${ }^{*}$ sti.steh.$t i$, while in a grammar prohibiting ssP violations in onsets, this candidate would be beaten by candidates without branching [st-] in the reduplicant. There is no conceivable ranking of alignment

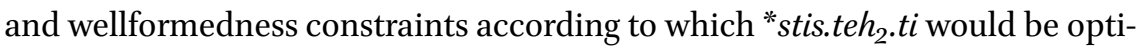
mal.

\section{4}

\section{sT-Clusters in Reduplication}

3.4.1

PIE ST-Initial Roots

Jasanoff (2003: 128ff.) sets up the present to $\sqrt{\text { ste }_{2}}$ 'stand' as an original reduplicated ${ }^{*} h_{2} e$ verb: $/ \operatorname{RED}\left(i^{\prime}\right)+\operatorname{ROOT}(\varnothing)$-e/, which was subsequently thematized with the breakdown of the ${ }^{*} h_{2} e$ conjugation: ${ }^{* *} s t i-s t h_{2}-e>{ }^{*} s t i-s t h_{2}-e / o-$. As Byrd $(2010,2012)$ has argued, the evidence of Latin, Avestan, and Greek indicates that PIE reduplicated only * si- and not *stí-. As such, the reduplicated present for PIE $\sqrt{s t e h} h_{2}$ can be derived as follows using the five oT constraints from $\S 3.3 .2$ above:

TABLE 2 Reduplicated present for PIE $\sqrt{\text { steh }_{2}}$ 'to stand'

\begin{tabular}{|c|c|c|c|c|c|}
\hline /RED-sth ${ }_{2}$-e-ti/ & RED-L & Root, $\sigma-\mathrm{L}$ & Root-L & $* \mathrm{M} / \mathrm{A} \triangleright \mathrm{T}$ & SSP \\
\hline a. sti.sth $_{2}$ e.ti & & & $* * *$ ! & & $* *$ \\
\hline b. $<$ s $>$ tis.th $_{2}$ e.ti & $* !$ & $*$ & $* *$ & & \\
\hline$\rightarrow$ c. si.sth ${ }_{2}$ e.ti & & & $* *$ & $*$ & $*$ \\
\hline d. tis.th ${ }_{2}$ e.ti & & $* !$ & $* *$ & & \\
\hline e. $<$ s $>$ ti.th ${ }_{2}$ e.ti & $* !$ & & $* *$ & & \\
\hline
\end{tabular}

In PIE, the highest-ranked constraints, the alignment constraints, all conspire to keep the reduplicant as small as possible. The winner, Candidate $\mathrm{c}$, does 
violate the two phonotactic constraints, but only after the other candidates have already been eliminated. We should not expect the ssp to be very highly ranked, since it is regularly violated in onsets in the general grammar. Because the SSP is ranked below the root alignment constraint, there is no reason for the sT cluster in the root syllable to be broken across a syllable boundary, as it is in both Candidate в and Candidate D. A reduplicant of the shape [ti-] like we see in Sanskrit (Candidate D) further incurs a violation of the root/syllable alignment constraint. ${ }^{13}$ Germanic-type full cluster reduplication (Candidate A) violates the root alignment constraint more than any of the other candidates by causing the reduplicant to be too long. Furthermore, the grammar has no reason to produce an extraprosodic $\mathrm{S}$ of the [spo.pon.di]-type (Candidate $\mathrm{E}$ ) or of the unattested full-reduplication type (Candidate B), because extraprosodic $S$ incurs a violation of the reduplicant alignment constraint.

This grammar will generate sistō in Latin and hištanti in Avestan, as well as Greek histēmi, which has been pulled into the *mi-conjugation. Like in Latin, in Greek, too, histemmi is an isolated relic apart from the regular reduplication pattern for sSP-violating initial clusters (i.e. Attic reduplication or augmented forms like héstēka 'stood (1st. sg. perf.)).'14 There's no reason to assume synchronic Latin or Greek grammars ever generated sistō or histēmi. The speakers merely conserved an archaism.

\subsubsection{Gothic ST-Initial Roots}

There is good evidence that the SSP is not highly ranked in Germanic languages: in English, for example, tautosyllabic sT clusters block aspiration on voiceless stops, since the voiceless stop is not initial in its syllable. According to articulatory phonological studies on American English (Marin \& Pouplier, 2010) and German (Pouplier, 2012), these languages show no difference in the timing of ST-clusters in comparison to the timing of TR-clusters, in contrast to the Italian data from Hermes et al. (2013:4) discussed above in $\S 1$.2. Note that all of these studies are completely inconsistent with Keydana's monosegment account (see $\S 2$ ), according to which we should expect monosegmental st to time as only one segment rather than two.

At least in terms of its reduplicative pattern, Gothic is very similar to PIE:

\footnotetext{
13 Sanskrit-type reduplication can also be penalized for violating anchoring constraints, not shown here. See Zukoff (2012).

14 For an excellent discussion of ssp violations and reduplication in Greek, see Zukoff (2012).
} 
TABLE 3 Gothic -staistald 'possessed'(3 sg. pret.)

\begin{tabular}{|c|c|c|c|c|c|}
\hline /RED-stald/ & RED-L & Root, $\sigma-\mathrm{L}$ & $* \mathrm{M} / \mathrm{A} \triangleright \mathrm{T}$ & RoOT-L & SSP \\
\hline$\rightarrow$ a. stai.stald & & & & $* * * *$ & $* *$ \\
\hline b. $<$ s $>$ tais.tald & $* !$ & $*$ & & $* * *$ & \\
\hline c. sai.stald & & & $* !$ & $* * *$ & * \\
\hline d. tais.tald & & $* !$ & & $* * *$ & \\
\hline e. $<$ s $>$ tai.tald & $* !$ & & & $* * *$ & \\
\hline
\end{tabular}

The only major difference between the Gothic and PIE reduplication is that PIE consistently reduplicated with only a single consonant and vowel, while in Gothic two consonants must be copied into the reduplicant when the onset cluster violated the ssp. The margin constraint penalizes the candidate sai.stald, similar to the PIE winner si.sth ${ }_{2}$ e.ti, for copying a less optimal onset consonant. This change in ranking was likely motivated by a generalization made by speakers concerning the type of consonants generally reduplicated. In most cases of reduplication, it is the less sonorous segment, which is also the most optimal word onset, that is copied. It will only be the case with ST clusters that the less sonorous segment is not the first segment. By copying both segments, speakers maintain their generalization at the expense of the root alignment constraint.

\subsubsection{Gothic TR-Initial Roots}

This grammar will not overgenerate full reduplication with roots that begin with falling-sonority clusters (such as TR-):

TABLE 4 Gothic gaigrōt 'wept' (3 sg.pret.)

\begin{tabular}{|r||c|c|c|c|c|}
\hline$/$ RED-gro:t/ & RED-L & RoOT,$\sigma-\mathrm{L}$ & $* \mathrm{M} / \mathrm{A} \triangleright \mathrm{T}$ & RoOT-L & $\mathrm{SSP}$ \\
\hline \hline a. grai.gro:t & & & & $* * * * !$ & \\
\hline$\rightarrow$ b. gai.gro:t & & & & $* * *$ & \\
\hline c. rai.gro:t & & & $* !$ & $* * *$ & \\
\hline
\end{tabular}

Here, the full redupliation candidate, ${ }^{*}$ [grai.gro:t], is not chosen as optimal—in contrast to [stai.stald] above-because it incurs unnecessary violations of the 
Root Alignment constraint. Both consonants of a cluster will only be copied if the left-most consonant in a branching onset is the more sonorous one: i.e., when there is a violation of the SSP.

\subsubsection{Latin ST-Initial Roots}

TABLE 5 Latin spopondī 'pledged'

\begin{tabular}{|c|c|c|c|c|c|}
\hline /RED-spond-ī/ & Root, $\sigma-\mathrm{L}$ & SSP & $* \mathrm{M} / \mathrm{A} \triangleright \mathrm{T}$ & RED-L & Root-L \\
\hline a. spo.spon. $d \overline{1}$ & & $* ! *$ & & & $* * *$ \\
\hline b. $<\mathrm{s}>$ pos.pon. $\mathrm{d} \overline{\mathrm{l}}$ & $* !$ & & & $*$ & $* *$ \\
\hline c. so.spon.d̄̄ & & $* !$ & $*$ & & ** \\
\hline d. pos.pon.d $\overline{1}$ & $* !$ & & & & ** \\
\hline$\rightarrow$ e. $<$ s $>$ po.pon.dī & & & & $*$ & $* *$ \\
\hline
\end{tabular}

Like the Gothic grammar above, in Latin we also see the margin constraint penalizing the copying of a less sonorous segment. The stop is preserved in reduplication because it is a less marked onset. Furthermore, the promotion of the SSP in the general grammar above the two alignment constraints (RED-L and Rоот-L) prevents sT-clusters from forming tautosyllabic branching onsets. This promotion would serve as a simplification of the Latin grammar; because sibilant-stop clusters are the only ones inherited into Latin that violate the SSP (after the loss of laryngeals), speakers would have no unambiguous data that the SSP is violable. Afterall, speakers do not seem sensitive to the small difference in phonetics between $[<\mathrm{S}>\mathrm{T}-]$ and $[\mathrm{ST}-]$ (for which, see the discussion of Italian above, §1.2). Therefore, because both structures are possible given the Latin lexicon, speakers could easily promote the ssp to unite all onsets according to sonority. ${ }^{15}$

While copying two root segments is anomalous in Latin grammar, the full deletion of the $[\mathrm{s}]$ (*[po.pon.dī], not shown above for ease of presentation) would cause output-output non-correspondence between the reduplicated form and the rest of its verbal paradigm. The /s/ had to surface somewhere, so just like in the rest of the verbal paradigm, it becomes extraprosodic word-

15 For more on the possible diachronic pathway leading to the promotion of the SsP in the general grammar, see DeLisi (2015: 96-103). 
initially. This extraprosodic s also does not cause further violations of the root alignment constraint, since the $s$ is outside the prosodic word (i.e., it is outside the scope of the constraint).

Note that there is nothing about this synchronic grammar that causes sisto to be phonotactically marked, but at the same time, it cannot be generated through productive morphological processes. Instead, one must assume it is merely lexicalized. This assumption does not seem unwarranted, especially considering in its paradigm sistō coexists with perfect stitī.

\subsubsection{Sanskrit sT-Initial Roots}

TABLE 6 Sanskrit tíșțhati 'stands'

\begin{tabular}{|c|c|c|c|c|c|}
\hline /RED-stha-ti/ & $\mathrm{SSP}$ & $* \mathrm{M} / \mathrm{A} \triangleright \mathrm{T}$ & RED-L & Root, $\sigma-L$ & Root-L \\
\hline a. sti.ṣtha.ti & $* ! *$ & & & & $* * *$ \\
\hline b. $<\mathrm{s}>$ tiș.tha.ti & & & $* !$ & * & ** \\
\hline c. si.ștha.ti & $* !$ & * & & & ** \\
\hline$\rightarrow$ d. tiṣ.ṭha.ti & & & & * & $* *$ \\
\hline e. $<\mathrm{s}>$ ti.tha.ti & & & $* !$ & & $* *$ \\
\hline
\end{tabular}

In Sanskrit, too, the ssp has been promoted in the general grammar, ${ }^{16}$ so we expect to see SSP effects in the reduplicative template, as well. The difference between the Sanskrit and Latin forms shows that in Sanskrit it is less costly to split the root-initial cluster across a syllable boundary (i.e., violate the root alignment constraint) than to allow a word-initial extraprosodic s (i.e., violate the reduplicant alignment constraint). In both languages, though, we see the effects of a conspiracy against tautosyllabic ssP-violating clusters. This is not to say the conspiracy was inherited; instead, these developments must have been completely independent.

Perhaps the difference between tis.thati and $\langle s>$.po.pon.dī should not be surprising. Sanskrit speakers would have had robust evidence that root-initial clusters need not be tautosyllabic after an inflectional morpheme; the augment would also cause the same kind of syllabification, as in as.thät 'stood (3. sg. aor.).' There would be no support in the rest of the lexicon, however, for the copying

16 See Kobayashi (2004:41 ff). 
of two root segments into the reduplicant. In Latin, precisely the opposite data would have been available to speakers; since no verbs are augmented in Latin, there would be no precedent in the language for root-initial clusters becoming heterosyllabic after inflectional prefixes. Judgments based upon the behavior of reduplication of SSP-violating clusters may have been less robust in Latin, since there are so few of them.

\section{4}

\section{Conclusions}

Most of the metrical evidence from the corpus of Latin poetry points to heterosyllabicity of ST-clusters. Short vowels before medial ST-clusters generally scan long by position (rather than short in an open syllable) in Plautus, and systematically scan long by position in the Classical Latin period. Brevis Brevians, the shorting of expected long syllables, which occurs in some words containing medial st cannot be understood as a true prosodic property of the language, since it also triggers short scansions before clusters that absolutely cannot be argued to form onsets in Latin (e.g., $n t$ and $r t$ ). Instead, Brevis Brevian must merely be a peculiar feature of archaic Latin poetry. Whatever its explanation is, it cannot be a reflection of syllable structure.

Synchronic phonological processes offer even clearer evidence for how speakers were treating the cluster. All of the processes pointing to tautosyllabic treatments of the cluster, open syllable syncope and evidence of the initial stress pattern, were active in the Pre-Literary period. Heterosyllabic treatments, such as closed syllable weakening and the stress pattern seen in dēsístō, inféstus, and incéstus, are all indicative of a later layer of the language. Both the tautosyllabic and heterosyllabic processes are consistent with the very early preservation of SSP violations in onsets inherited from PIE and a later promotion of the ssP during the Pre-Literary period. The only form that contradicts this neat story is praefiscini, with unexpected open syllable treatment of the weakened vowel. As Nishimura (2008: 139, fn 34) points out, this form is problematic for most formulations of the weakening rule.

The morphological evidence of reduplication corroborates the story told by these synchronic phonological processes. The only form pointing to retention of sT-branching onsets is sistō; However this word is merely a relic of the parent language. Because it is completely isolated in the language and corresponds perfectly with Avestan and (with a different stem formation) Greek, it's not necessary that any stage of Latin be capable of synchronically generating it. Instead, the grammar of Latin must be able to explain the morphophonological form of the spopondi-type. The grammar of the parent language cannot 
generate this reduplication type, and it's not easily compared to any other branch's reduplication. Thus, it must be an innovation of Latin. It points very clearly to a stage of Latin after the SsP has been promoted, since it requires an extraprosodic $\mathrm{S}$ structure.

The attestation of this reduplication type already in the text of Plautus further shows that by the time of the Early Republic poets, ST clusters must have been heterosyllabic, and therefore Brevis Brevians scansions must not be a reflection of the synchronic language.

Although branching onsets with violations of the Sonority Sequencing Principle were inherited from PIE, ST-clusters must have ceased being tautosyllabic very early, perhaps by the end of the Pre-Literary period. By Classical Latin, medial $s$ is certainly not tautosyllabic with adjacent stops anymore. The early attestation of the spopondi-type of reduplication shows that $s$ in an initial sibilant-stop cluster was already extraprosodic in Plautus, contrary to the implications of Brevis Brevians scansions before sT. The phonological evidence of syncope, weakening, and accentuation also support the early change from tautosyllabic to heterosyllabic treatment. Extraprosodic s has been retained into Modern Romance, with the exception of Romanian, which has re-developed branching onsets with falling sonority.

\section{Acknowledgements}

An early version of this paper was presented at the Workshop in Indo-European at Kyoto University, Kyoto, Japan. My thanks are due to Andrew Byrd, Steven Faulkner, Caley Smith, Brent Vine, Anthony Yates, two anonymous reviewers, and the participants of the workshop for their valuable feedback. I am also indebted to Ben Fortson for his help with Plautine meter. All errors and omissions that remain are, of course, my own.

\section{References}

Adams, J.N. 2007. The regional diversification of Latin $200 B C-A D$ 6oo. Cambridge: Cambridge University Press.

André, Jacques. 1978. Les mots à redoublement en latin. Paris: C. Klincksieck.

Becker, Michael, and Katherine Flack Potts. 2011. The emergence of the unmarked.

The Blackwell Companion to Phonology, ed. by Marc van Oostendorp, Colin J. Ewen,

Elizabeth Hume, and Keren Rice, vol. 3, 1363-1379. Malden, MA: Wiley-Blackwell.

Byrd, Andrew M. 2010. Reconstructing Indo-European syllabification. UCLA dissertation. 
Byrd, Andrew M. 2012. Predicting Indo-European syllabification through phonotactic analysis. The Sound of Indo-European-phonetics, phonemics, and morphophonemics, Copenhagen, 16-19 April 2009, ed. by Benedicte Nielsen Whitehead, Thomas Olander, Birgit Anette Olsen, and Jens Elmegard Rasmussen, 9-28. Copenhagen: Museum Tusculanum Press.

Cho, Young-mee Yu. 1998. Language change as reranking of constraints. Historical Linguistics 1995, vol. ii Germanic Linguistics, ed. by Richard M. Hogg and Linda van Bergen, 45-62. Amsterdam: John Benjamins.

Cho, Young-mee Yu, and Tracy Holloway King. 2003. Semisyllables and universal syllabification. The Syllable in Optimality Theory, ed. by Caroline Féry and Ruben van de Vijver, 183-212. Cambridge: Cambridge University Press.

DeLisi, Jessica. 2015. Epenthesis and prosodic structure in Armenian: A diachronic account. UCLA dissertation.

Fleischhacker, Heidi Anne. 2005. Similarity in phonology: Evidence from reduplication and loan adaptation. UCLA dissertation.

Fortson, Benjamin W. IV. 2008. Language and rhythm in Plautus: Synchronic and diachronic studies. Berlin: Walter de Gruyter.

Green, Anthony Dubach. 1997. The prosodic structure of Irish, Scots Gaelic, and Manx. Cornell University dissertation.

Halporn, James W.; Martin Ostwald; and Thomas G. Rosenmeyer. 1980. The meters of Greek and Latin poetry. Reprint, revised edn.: Hackett.

Harris, James W. 1970. A note on Spanish plural formation. Language 46.928-930.

Hermes, Anne; Doris Mücke; and Martine Grice. 2013. Gestural coordination of Italian word-initial clusters: the case of 'impure s'. Phonology 30.1-25.

Holt, D. Eric. 2003. Remarks on Optimality Theory and language change. Optimality Theory and Language Change, ed. by D. Eric Holt, 1-30. Dordrecht: Kluwer Academic Publishers.

Jasanoff, Jay H. 2003. Hittite and the Indo-European verb. New York: Oxford University Press.

Juret, A.C. 1919. Influence de la position sur l'évolution du timbre des voyelles brèves en latin. Mémoires de la Société de Linguistique 21.93-107, 166-186.

Kavitskaya, Darya. 2001. Hittite vowel epenthesis and the sonority hierarchy. Diachronica $18.267-299$.

Keydana, Götz. 2010. Evidence for non-linear phonological structure in Indo-European: The case of fricative clusters. Unpublished extended version of Keydana 2012. Online: http://www.keydana.de/download.php?id=Keydana_Fricative_Clusters_ extended_version.pdf

Keydana, Götz. 2012. Evidence for non-linear phonological structure in Indo-European: The case of fricative clusters. The sound of Indo-European-phonetics, phonemics, and morphophonemics, Copenhagen, 16-19 April 2009, ed. by Benedicte Nielsen 
Whitehead, Thomas Olander, Birgit Anette Olsen, and Jens Elmegard Rasmussen, 223-241. Copenhagen: Museum Tusculanum Press.

Kiparsky, Paul. 2004. Fenno-Swedish quantity: contrast in stratal от. Ms., Stanford University.

Kobayashi, Masato. 2004. Historical phonology of Old Indo-Aryan consonants. Tokyo: Tokyo University of Foreign Studies.

Lindsay, Wallace M. 1904-1905. T. Macci Plauti comoediae. Oxford: Clarendon.

Marin, Stefania. 2013. The temporal organization of complex onsets and codas in Romanian: A gestural approach. Journal of Phonetics 41.211-227.

Marin, Stefania, and Marianne Pouplier. 2010. Temporal organization of complex onsets and codas in American English: Testing the predictions of a gestural coupling model. Motor Control $14.380-407$.

Marotta, Giovanna. 1999. The Latin syllable. The syllable: Views and facts, ed. by Harry van der Hulst and Nancy A. Ritter. Berlin: Mouton de Gruyter.

McMahon, April M.S. 2000. Change, chance, and optimality. Oxford: Oxford University Press.

Mynors, R.A.B. 1978. P. Vergili Maronis opera. Oxford: Clarendon.

Nishimura, Kanehiro. 2008. Vowel reduction and deletion in Italic: Effects of stress. UCLA dissertation.

Nishimura, Kanehiro. 2011. Syncope in Latin: a historical restatement of its conditions. International Journal of Diachronic Linguistics and Linguistic Reconstruction 8.141.

Pouplier, Marianne. 2012. The gestural approach to syllable structure: Universal, language-, and cluster-specific aspects. Speech planning and dynamics, ed. by Susanne Fuchs, Pascal Perrier, Daniel Pape, and Melanie Weirich, 63-96. Frankfurt: Peter Lang.

Prince, Alan, and Paul Smolensky. 1993/2004. Optimality Theory: Constraint interaction in generative grammar. Malden: Wiley Blackwell. Ms., Rutgers University, New Brunswick, N.J., and University of Colorado, Boulder.

Rix, Helmut. 1966. Die lateinische Synkope als historisches und phonologisches Problem. Kratylos 11.156-165.

Sommer, Ferdinand, and Raimund Pfister. 1977. Handbuch der lateinischen Laut- und Formenlehre: Eine Einführung in das sprachwissenschaftliche Studium des Lateins, vol. I: Lehr- und Handbücher. Heidelberg: Carl Winter.

Tarrant, R.J. 2004. P. Ovidi Nasonis Metamorphoses. Oxford: Clarendon.

Vaux, Bert, and Andrew Wolfe. 2009. The appendix. Contemporary views on architecture and representations in phonology, ed. by Eric Raimy and Charles Cairns, 101-143. Cambridge: MIT Press.

Weiss, Michael. 2009. Outline of the historical and comparative grammar of Latin. Ann Arbor: Beech Stave. 
Wickham, Edward C. 1922. Q. Horati Flacci opera. 2nd edn. Oxford: Clarendon.

Zukoff, Sam. 2012. The phonology of verbal reduplication in Ancient Greek: An Optimality Theory approach. Master's thesis, University of Georgia. 